2020, Volume 10, International Conference Globalization, Innovation and Development. Trends and Prospects (G.I.D.T.P.), pages: 160-171 |

https://doi.org/10.18662/lumproc/gidtp2018/19

\section{Comparative Study on the Regulation of Group Companies Accounts Consolidation - Anglo- Saxon Approach versus Continental Approach}

\section{Violeta STATE* ${ }^{1}$, Raluca Andreea STOICA ${ }^{2}$ \\ ${ }^{1}$ Valahia University, Targoviste, Romania, viostate@yahoo.com Corresponding author}

2 Valahia University, Targoviste, Romania, raluca2stoica@yahoo.com
Abstract: The contemporary configuration of economies covers a variety of processes. Firstly, this corresponds to the opening of savings to international transactions and the development of the exchange of goods and services. Secondly, the international mobility of production factors, and especially of capital, denotes what we need to understand through globalization. Globally, companies in the group are an economic unit, to be presented as a whole. In this respect, it is necessary to prepare consolidated financial statements by integrating the individual financial statements of the members of the group. Following the establishment of the reference framework and the conceptual coordinates of the consolidated financial statements, we continued the scientific approach by addressing the main relevant regulations at international, European and national levels, analyzing the evolution over time, existing interdependencies and current status. We presented the evolution of the accounting normalization process in order to highlight the interest for creating accounting norms that will ultimately lead to a unitary mode of action and application in order to achieve comparability of content and interpretation of accounting information. We have followed this process of accounting convergence both at the level of international, European and U.S. institutions, as well as at the level of our country, Romania.

Keywords: globalization; euro-accounting harmonization; restatement; consolidation.

How to cite: State, V., \& Stoica, R.A. (2020). Comparative Study on the Regulation of Group Companies Accounts Consolidation - Anglo-Saxon Approach versus Continental Approach. In I. Panagoreț \& G. Gorghiu (vol. ed.), Lumen Proceedings: Vol. 10. International Conference Globalization, Innovation and Development. Trends and Prospects (G.I.D.T.P.) (pp. 160-171). Iasi, Romania: LUMEN Publishing House. https://doi.org/10.18662/lumproc/gidtp2018/19 


\section{Introduction}

The groups of companies are currently in a continuous development, being the direct consequence of the global economy's evolution towards the intensification of international capital movements. The phenomenon of the group of companies has expanded over the last decades, covering a wide range of business sectors, with multinational groups occupying a central place in the developed economies, whether industrial, commercial or banking, listed or not.

In this context, the group of societies is constituted as a stand-alone economic unit, the knowledge of the financial situation and the performances obtained at the level of each group of societies, viewed as a unitary one, being a necessity.

The issue addressed relates to how to regulate financial reporting at the level of multinational corporations, within the same group being economic entities from countries whose financial accounting system differs according to the rules of the applicable accounting system nationally.

The objective of this paper is to highlight the importance of the consolidation techniques in the context of the evolution of international accounting systems towards accounting convergence and compliance.

Accounting standardization is the process by which the presentation of financial statements, accounting methods and terminology are harmonized. It aims at creating rules or accounting rules that are refined so as to represent a common denominator of the actions regarding their application in that for assure the comparability of content and treatment of accounting information.

In this regard, we have conducted comparative documentary research, focusing on two of the accounting systems that have evolved over time at European level, namely the Anglo-Saxon and Continental.

\section{Groups of companies and the evolution of legal bases to regulate their consolidation}

In the context in which within the group of companies, each entity, considered individually, performs the financial reporting in accordance with national accounting provisions, the consolidated reporting of the financial situation and the performance of the group requires the adoption of regulations that lead to obtaininga fair, complete and clear image of all the societies considered an entity respectively the group of which they belong. 
The process of creating regulations in accounting has generated two streams over time:

- Conceptual or deductive current in which accounting rules are established by professional reasoning, relying on methods and procedures subsequently applied in practice, which led to the creation of the continental accounting system;

- The pragmatic or inductive current in which concepts and principles are drawn from experiences and traditions, which led to the creation of the Anglo-Saxon accounting system (also adopted by the US).

Each country has its own accounting system that reflects the legal, social and cultural influences specific to that country, but the different national accounting systems with their specificities can be grouped more or less faithfully and integrated into one of the two models.

In the Anglo-Saxon model, the state does not intervene in the elaboration of the rules but only in their implementation. We are talking here about a normalization of the annual financial systems of the Anglo-Saxon states (US), concerning the "content" of the financial statements and their elements, the regulations, the rules relating to the treatment and presentation of the information in the accounting documents. In the sphere of normalization, the order, the format in which the elements contained in the financial statements must be presented, is not prescribed. Preferential users here are "investors."

In the case of the continental model, the state has a major role to play both in the process of normative labor and in its implementation. Normalization with the general accounting plan "is the property of the countries of Continental Europe, and the syntax of the accounting plan belongs to the accounting of France"[1]. The normalized elements are: the content and the presentation form of annual financial statements, general accounts plan (name, symbol, content and accounting function of every account), organization of the whole accounting system. In this case, the "preferential" user is the state.

So, we can talk about an internationalization of accounting that has its source in the preoccupations of international harmonization of rules and accounting practices. One of the goals pursued through the internationalization of accounting is to facilitate the preparation of consolidated accounts which means integrating the individual situations of group members.

Consolidating the financial statements (accounts) is therefore the direct consequence of the development of the groups of companies and, implicitly, the increased need for financial information related to them. 
The United States has its oldest concerns in the area of consolidation of accounts. The emergence of the first American holding in 1832 made it possible to publish the first consolidated financial statements in 1891, despite the fact that at that time there was no regulation in the field. The continued concern of shareholders, group managers, financial analysts, stockbrokers, banks and unions to know the financial position and performance of a group of companies has prompted many companies to include consolidated financial reports in their reporting.

The creation of the first professional accountancy organization (1897) led to a greater focus on accounting normalization and the provision of realistic and complete financial information on groups of companies. Thus, the work of the first international congress organized by the American Institute of Certified Public Accountants in Saint Louis in 1904 highlighted the insufficiency of information provided by individual accounts by holding companies, recommending professional accountants to produce consolidated statements. As a result, since 1910, the most important companies have replaced individual accounts with consolidated financial statements.

In 1934, the Securities Exchange Act, an independent governmental body with control over securities trading, was set up. The Securities Act of 1931 and the Securities Exchange Act of 1934 required the preparation of consolidated financial statements.

In 1959, the Securities Commission publishes the first accounting rules (ARB 51 - Accounting Research Bulletins) containing express regulations for accounting for business combinations, while consolidation perimeters, general consolidation techniques, minority interests, and dividend regimes are dealt with.

In 1973, the Financial Accounting Standards Board (FASB) was set up as an independent body, which was given full authority to lay down general accounting rules and financial statements. To date, more than 100Standards of Financial Accounting Standards (SFAS) have been published, replacing those issued by ARB and the Accounting Principle Board (APB - Accounting Principles Board).

In the United Kingdom, in 1922, the first consolidated accounts were published by Nobel Industries Limited. Then, in 1939, the London Stock Exchange issued a provision that introduced the requirement for consolidated accounts to be drawn up by quoted companies. At the same time, there is also a recommendation by professional accountants to consolidate their accounts. In 1944, the first Statement of Standards Accounting Practice (SSAP), the 14th execution standard, appears. Since 
1948, through the "Companies Act", the publication of consolidated accounts becomes mandatory.

In Germany, in 1967, the publication of consolidated accounts for capital companies is mandatory, and since 1968 this obligation applies also to limited liability companies.

In France, the publication of the first consolidated accounts took place only in 1966. In 1968 the first recommendation of the National Accounting Council (NCC) was issued and, since 1985, consolidation became mandatory. The following year, the Decree of February 17 and the Consolidated Methodology of the National Accounting Council, implemented through a ministerial order, were implemented. The guidelines for consolidation regulation are also the recommendations of the Commission for Scholarship Operations (COB).

Regarding Romania, we can say that in the EU accession strategy we considered the improvement of the business environment in which the role of accounting and financial audit systems was to provide quality information for decision making. This required the harmonization of national accounting with the European Directives and with the provisions of international accounting standards.

Romania chose to implement a continental accounting system, the process of accounting reform began in 1990, but the issue of consolidation has explicitly appeared in 2001. From then until now the process of accounting regulation at national level has led to the elaboration of some regulations that have been modified and supplemented so as to keep up with the international evolution of the accounting normalization process.

At the moment, in Romania, the accounting regulations approved in 2014 are applied, which have followed the integration in the national legislation of the European directives regarding the individual and consolidated reporting.

\section{Consolidation of group companies accounts - concept and objectives}

The concern of the accounting professionals for the most accurate reflection of the reality in accounting, has resulted in the emergence of a specific terminology, which in time, was adopted almost unanimously, terms like the U.S. G.A.A.P standards or I.F.R.S or I.A.S. being key in the international accounting language.

The current period demonstrates that, between the two recognized international references, there is a different logic of normalization. 
In the case of European countries, the elaboration of national standards based on the principles of the I.A.S./I.F.R.S. requires good knowledge of them and a legislative activity to prepare the framework necessary for the opening of the field of application and the unhindered manifestation of these principles.

National standards so elaborated must ensure total convergence with the I.FRRs, from this point of view the process of harmonizing the Romanian accounting with the requirements of I.A.S./I.F.R.S and with the U.E. is one of the greatest challenges for our country's administration.

This way of accessing international standards can ensure a better match between principles and rules, can better meet the relationships that need to exist between accounting and taxation.

The most important result of the normalization process is the definition of postulates and accounting principles, which have a general sphere of application and the specific accounting rules applicable in certain cases.

"Account consolidation is an accounting technique or process that allows accounting for and a single presentation of the overall activity and the situation of a group of companies having a common interest or legal personality"[2]. Consolidation allows the presentation of financial statements, respectively a balance sheet and the result of the companies forming the group as if it were only one enterprise. Legal entities in the same group assume the existence of all independent accounts, but are unable to highlight the complete image of the group, from an economic and financial point of view.

In many groups, the parent company is effectively a holding company that does not carry out any industrial or commercial activity. Its balance sheet includes participation titles which allow the exercise of control or influence over other companies, either from loans to group companies.

The parent's individual financial statements reflect, in this case, only the registered participations or the dividends they have received and which they have recorded in the profit and loss account. Therefore, they do not present a true image of a group's economic, financial or industrial power, as it does not reflect the nature and importance of the assets and liabilities of the entities that form the group, the characteristics of their operating activity, such as turnover and costs, the level of their results.

It follows from the above that the objective of consolidation is to "present the financial position, performance and evolution of the financial position of entities in the group as if it were a single undertaking"[3]. 
The consolidated documents must ensure the comparability of the data reported, in time and space, which means that they must comply with the applicable general rules.

\section{Comparative study on restating the accounts and operations of homogenization - between regulation and enforcement}

Operations within the consolidation process are often in a nonuniform and / or international legal and accounting framework. It is common for a group to be composed of companies that have different economic activities and / or different geographical implants. In order to obtain a standardized and pertinent image of this economic entity, the sources of accounting information must undergo a true filtering through a series of operations commonly referred to as "homogenization" [5].

As a general rule, consolidated accounts can not be obtained by direct aggregation of the individual accounts of the undertakings forming the consolidation perimeter as individual accounts can be drawn up according to different rules depending on the geographical area in which the companies to be consolidated are operating. Individual accounts are also drawn up in accordance with legal and tax regulations that are different from those applicable in the consolidation process.

For these reasons, the rules on consolidation of accounts set out a basic principle of consolidation, namely homogenization.

This principle is not limited to providing a common accounting language for individual accounts, but also involves the reprocessing or reclassification of accounting items that mainly target the application of homogeneous valuation methods in the consolidation process.

Homogeneity refers to the assets and liabilities of the balance sheet, to the items of income and expense, to the information contained in the notes, in other words, to all the financial statements of the company.

This process is not done randomly, but is based on a consolidation plan that preserves the most appropriate rules and methods for the group in question to get a true picture of the financial situation and the performances.

Where an enterprise in the group uses accounting methods other than those included in the consolidation plan in the treatment of operations, adjustments should be made to achieve the intended homogeneity. However, if these elements are insignificant in relation to the size of the group or if the cost of obtaining homogenised data is too high in relation to the effects obtained, the aboveadjustments may be waived. This respects the implementation of the principle of relative importance. 
The subject of the comparative study is a group of companies whose particularities are presented below.

Alpha Ltd is a marketing technology company that has as beneficiaries a number of recognized agencies and brands worldwide. By using Intelligence Brand technologies it is possible to have a better understanding of the beneficiaries, their mentality and interests, offering the possibility for the traders to plan and activate multi-channel media sessions.

Alpha DE is one of the Alpha Ltd subsidiaries, one of the largest telecommunications companies in the world, which runs businesses on all continents.

The Group prepares consolidated financial statements [4] under the Companies Act 2006, a law of the UK Parliament that is the main source of UK company law.

The homogenization process involves homogenizing the (temporal) reporting period, homogenizing the evaluations, homogenizing for disposal and homogenizing for aggregation.

\section{Homogeneity of the reporting period (time)}

It aims to ensure that financial information prepared for the same reference date is integrated in the consolidation process. The consolidated accounts of a group of companies are prepared and published each year, generaly they are determined at the same period and closing date as the parent's annual financial statements, except for particular situations specifically mentioned in the legislation applicable.

European and international law provides that if the dates for the exercise of an enterprise are consolidated no earlier than three months after consolidation of the consolidated accounts, they are drawn up on the basis of provisional accounts.

The parent company may consolidate directly the annual account set at a date earlier than the one for the consolidated accounts, subject to the mandatory drafting procedure, the deletion of the intragroup accounts and the assurance that this deviation of data is not likely to distort the images of the believer group.

For the subject group of the study, the individual financial statements used in the consolidation have the same reporting term.

\section{Homogenizing evaluations}

Consolidated accounts are established on the basis of the general accounting principles and rules of valuation so that they are the same as for individual accounts. 
If there are divergences between the valuation rules applicable to individual accounts and those applied to consolidated accounts, reimbursements will be made in individual accounts. Restructuring will allow a set of records to be applied to a group enterprise for group rating methods instead of the valuation methods held in individual accounts.

Some of the complementary, optional, specific consolidation methods and rules are:

Conversion differences: occur as a result of the need to expose the Group's reporting currency to transactions in another currency in the individual accounts of the subsidiaries. It is permissible to record these conversion differences, the profits may be retained, contrary ofgeneral accounting provisions regarding the individual accounts that only ensure the maintenance of inactive losses.

Alpha Group, apply I.A.S. 21 which regulates the way of transposing into accounting the effect of the changes of exchange rates, so that the consolidated statements can be presented in a single currency.

The functional currency of the group presented above is GBP:

Table 1. Conversion differences

\begin{tabular}{llll}
\hline Elements & EUR & Exchange rate & GBP \\
\hline Turnover & $1.024 .022,83$ & 0,8735 & $894.504,42$ \\
Total expenses & $971.613,17$ & 0,8735 & $848.723,54$ \\
Net result & $22.374,93$ & 0,8735 & $19.544,95$ \\
\hline
\end{tabular}

\section{Homogenisation to eliminate the influences of intra-group operations}

The fundamental principle of consolidation starts from the premise that a group is a unique entity. This leads to the removal of records from the individual accounts of group companies that refer to reciprocal or nongenerating transactions as well as dividends distributed within the group.

After this first group of homogenizations, removals can be made effectively. By their nature, removals can be of a patrimonial, financial, economic and fiscal nature.

Financial Discrepancies: refers to the reciprocal accounts contained in the annual documents of the group companies in the form of claims on a company and the debts to the other, of the income of a company and of the expenses in another without affecting the outcome at the level of group.

Elimination of an economic nature refers in particular to operations that generate results in one of the group companies as a result of internal transactions between them. These transactions may include: asset 
transfers, product sales between group units, internal provisions, formation expenses, and internal dividends.

Table 2. Elimination of an economic nature

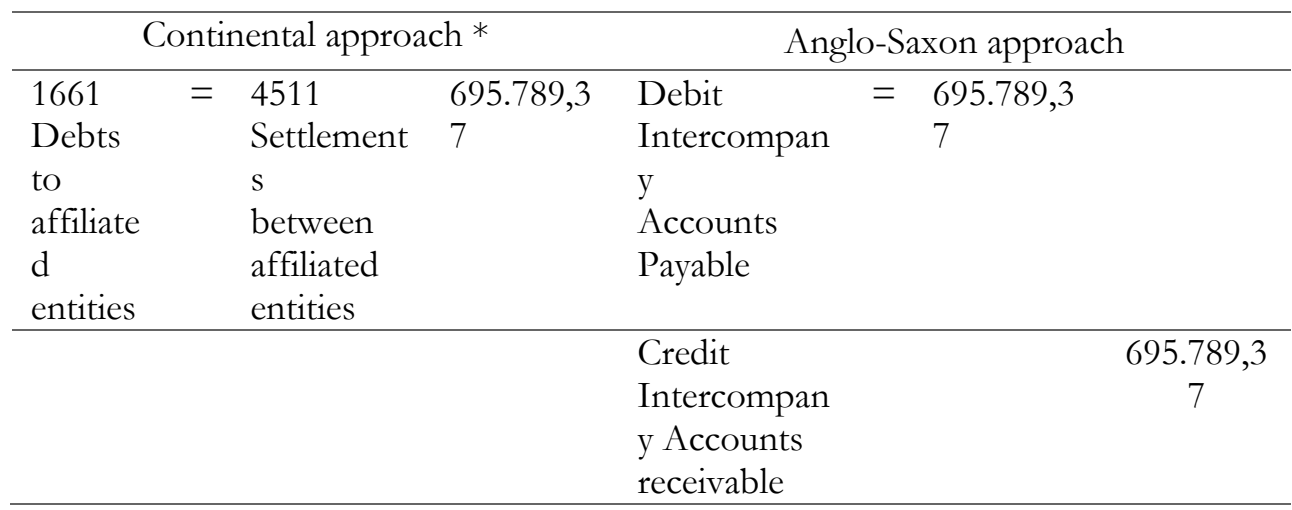

* the accounts used to exemplify are part of the General Account Plan used in Romania that adopted the Continental Accounting System.

Product sales between group units: The issue of elimination occurs if the products or merchandise sold by a unit in the other group have generated for the first result. This should be eliminated as products circulate between the two units of the group, eliminating them, whether stored, consumed or sold.

Table 3. Elimination of sales between group units

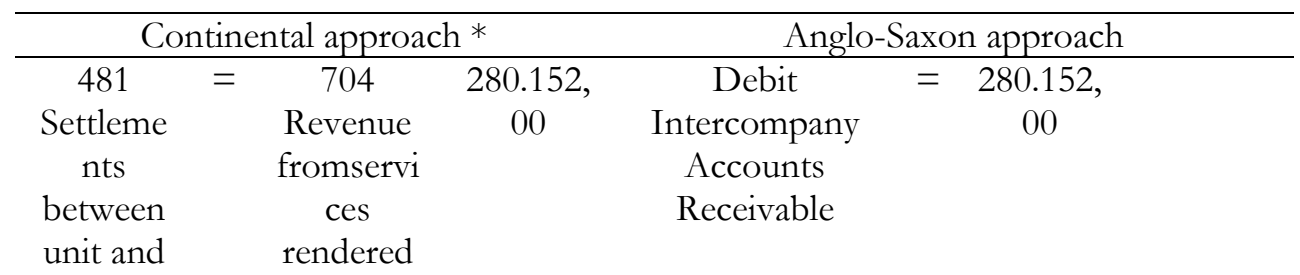

subunits

CreditIntercom 280.152 pany Sales

* the accounts used to exemplify are part of the General Account Plan used in Romania that adopted the Continental Accounting System.

Internal provisions are provisions in the group that refer to reversible write-downs of receivables on the group's reciprocal operations that are eliminated as they become unnecessary as a result of consolidation.

Set-up costs include start-up costs and capital expenditures, which generally target expenditure designed to ensure the legal structure of companies and their operation. At the level of consolidated accounts, 
companies, although independent entities, disappear. Therefore, training costs must be deducted and assimilated to the expenses of the year in which they were incurred, which means that they will affect the outcome.

Internal dividends are dividends received during the current year by a consolidated company from another consolidated company and already included in the company's profit for the preceding year. These are reflected in consolidated revenue from the previous year and in order to avoid double use of these earnings as a result of maintaining the same amount in consolidated profit for two consecutive years, it is necessary to eliminate them from the consolidated income of the current year.

Table 4. Elimination of intra-group dividends:

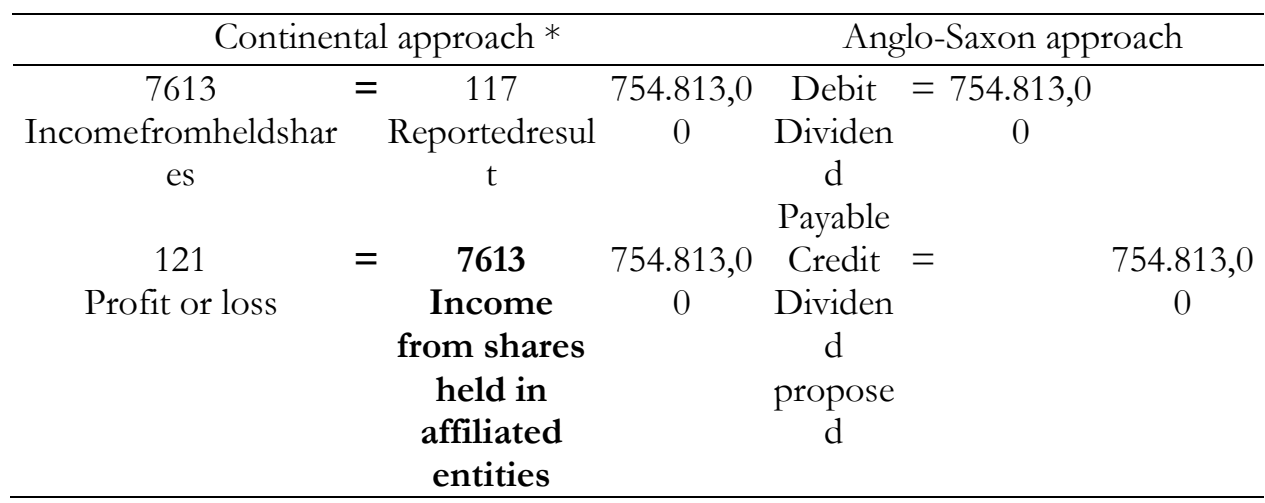

* the accounts used to exemplify are part of the General Account Plan used in Romania that adopted the Continental Accounting System.

\section{Conclusions}

The declared tendency of globalization of the national economies, determines more and more companies with sometimes unique but diversified and multiple objects of activity, to jointly seek a growth strategy, developing in this sense a network of multiple relations, going from the simplest ones to the most complex, from the deepest, to the most superficial.

As an economic reality, the group appears as a set of economic means belonging to the various companies that have common interests, means that they use together to realize an industrial, commercial or financial strategy.This is why the need to draw up consolidated financial statements in addition to the individual financial statements of the group members appeared. 
The objective of the consolidated statements is to present the financial position, performance and financial evolution of the entities included in the group of companies as if they were one company.

In any company, but especially in a group of companies, the substantiation of managerial decisions and, in particular, investment has become a necessity as a result of the risks that may arise and cause a failure of the actions taken but also because of the significant costs involved in the adoption and implementation of an inappropriate decision.

Getting the information provided in the consolidated financial statements is a real and sound basis for substantiating investment decisions, strategic decisions and, last but not least, executive management decisions. An investment decision based on reliable, comparable, consolidated and realistic accounting information is subject to a high degree of success.

\section{References}

[1]. Feleagă N, Feleagă L. Contabilitate financiară. O abordare europeană şi internațională, vol. I- Contabilitate financiară fundamentală. București: Editura Economică; 2007.

[2]. Lefebvre F. Memento Pratique Comptable. Paris: Editions Francis Lefevre; 1990.

[3]. Malciu L, Feleagă N. Reglementare şi practici de consolidare a conturilor Din orele astrale ale Europei contabile. Bucureşti: Editura CECCAR; 2004.

[4]. Mfandaidza RH. Consolidated Financial Statements: An International Perspective. Juta and Company Ltd; 2006.

[5]. Montier J, Scognamiglo G. Téchniques de consolidation. Paris: Editura Economica; 1995. 